\title{
When do we fly again? Managing Airlines in a Pandemic: Challenges and Recommendations
}

\author{
Mark Loo ${ }^{a}$, Pantri Heriyati ${ }^{b}$, Dewi Tamara ${ }^{c}$, Marko Hermawan Sebira ${ }^{d}$ \\ ${ }^{a}$ Faculty of Management, Concordia University of EdmontonEdmonton, Canada \\ ${ }^{\mathrm{b}}$ Management Department, Doctor of Research in ManagementBinus Business School, Bina Nusantara UniversityJakarta, \\ Indonesia \\ ${ }^{c}$ Management Department, Magister in Management, Binus Business School, Bina Nusantara University, Jakarta, Indonesia \\ dManagement Department, International Undergraduate Program, Binus Business School, Bina Nusantara University \\ Jakarta, Indonesia \\ åmark.loo@concordia.ab.ca, ${ }^{b}$ pheriyati@binus.edu, ${ }^{c}$ dtamara@binus.edu, ${ }^{\mathrm{d}}$ marko@binus.edu
}

Article History: Received: 10 November 2020; Revised 12 January 2021 Accepted: 27 January 2021; Published online: 5 April 2021

\begin{abstract}
This paper aimed to identify the challenges and propose recommendations to manage sustainability of the airline industry in a pandemic. When the World Health Organization stated Covid-19 as pandemic on March 11, 2020, governments in all countries ordered lockdowns, imposed travel restrictions, and required quarantine of 14 days for visitors and citizens upon arrival at the airport. The airlines industry came to a standstill. As Covid-19 is a recent and evolving phenomenon, the methodology employs secondary research based on data from authoritative sources such as the World Health Organization, International Civil Aviation Organization (ICAO) and International Air Transport Association (IATA) to identify the challenges. Peer reviewed research on past pandemics, especially the Severe Acute Respiratory Syndrome (SARS) in 20022003 help formulate recommendations to manage sustainability. The challenges are financial crisis, travel restrictions and customer distrust. The recommendations are positioning customer safety first, customer engagement, pricing strategy and collaboration with government. Limitations of the research and future research suggestions are presented
\end{abstract}

Keywords: Covid-19, Pandemic, Airline, Air Travel, Consumers, Safety, Challenges, Recommendations

\section{Introduction}

The World Health Organization (WHO, 2010) explains "pandemic" as 'worldwide spread of a new disease.' (WHO, 2010). On December 31 2019, China stated "a cluster of cases of pneumonia" in Wuhan, city in Province of Hubei (WHO Timeline - Covid-19, 2020), and WHO tweeted on January 14, 2020 that "preliminary investigations conducted by the Chinese authorities have found no clear evidence of human-to-human transmission of the novel \#coronavirus (2019-nCoV) identified in \#Wuhan, \#China" (Givas, 2020). By February 11, 2020, WHO officially named Covid-19 as the disease ("Coronavirus disease named Covid-19," 2020), and by March 12, 2020, WHO declared Covid-19 a pandemic ("WHO announces Covid-19 outbreak a pandemic," 2020).

On February 29, WHO advised against the application of travel or trade restrictions to countries experiencing Covid-19 outbreaks (Updated WHO recommendations for international traffic in relation to Covid-19 outbreak, 2020). As the virus spread to 20 countries mostly in Europe and the Middle East by February. several countries repatriated their personnel from China and banned travel or imposed travel restrictions (Yeung, 2020). Further, the influx of "coronavirus crisis tourists" fleeing the virus from their country and potentially spreading the virus to each holiday destination compelled the recipient countries to impose quarantines upon arrival and eventually ban outbound and inbound travel (Hutton, 2020).

With WHO's declaration of Covid-19 pandemic on March 12, governments around the world issued lockdowns and applied travel restrictions to foreign visitors and citizens from travelling abroad or interstate and some even monitored movement of people in the effort to stop the virus from spreading further (Yi, 2020; Kong, 2020; Salcedo, Yar \& Cherelus, 2020).

In April 2020, Global Web Index's survey among respondents aged16 to 64 in 17 countries found an increase in online shopping time led by China at $67 \%$ and New Zealand, last at $15 \%$ of respondents. Out of 13 identified online purchase categories, the top 12 were supermarket products led by food and grocery purchase at $33 \%$ and the last and lowest rated was vacation at 3.6\% (Kemp, 2020). Similarly, while ContentSquare reported week April $8-15$ showed an increase by $251 \%$ in visits and $76 \%$ in transactions in supermarket compared to prelockdown levels, traffic to tourism related websites dropped by $72 \%$ and transactions registered a $92 \%$ drop 
(Bellaiche, 2020). Almost overnight air travel came to a halt and as the months dragged on, the sustainability of airlines became increasingly challenging.

\section{Objective}

This paper intended to reveal the challenges and propose recommendations to manage sustainability of the airline industry in the Covid-19 pandemic.

A search on literature related to Covid-19 showed articles related to the scientific and medical aspects of the disease such as investigating origin (Guo et al., 2020), epidemiology (Bi et al., 2020), transmission and air-borne transmission (Zhang, 2020), clinical therapies (Guo, 2020), pathogenesis (Mason, 2020), pathophysiology (Yuki, 2020), radiology (Hosseiny. 2020), efficacy and safety of corticosteroids in Covid-19 (Ye, 2020), and the virus in 7780 pediatric patients (Hoang, 2020). There was a lack of research evidence on the impact of Covid-19 on business such as the airline and travel industry.

The closest coronavirus outbreak to Covid-19 was the Severe Acute Respiratory Syndrome (SARS). Although LeDuc and Barry (2004) described SARS as the first pandemic of the $21^{\text {st }}$ century, WHO classified SARS as an epidemic where it affected 26 countries and reported more than 8000 cases in 2003 ("SARS," n.d.).

Wilder-Smith (2006) described SARS and travel as linked one another, because if the travelers has infected, they become the carrier of the disease, and transmitted others. Then the spread of the virus will damage the travel and tourism industry. At that time, the epidemic of SARS already produced widely fear because of its novelty, its contagiousness, and its blowout through travellers, with addition to huge media reportage. The authority such as The Centers for Disease Control advised people not to go to affected areas in China, Vietnam, Singapore, and Hong Kong. However, the effect to international travel was short and limited because the airlines industry still operated (Sehl, 2020).

Based on Zeng, Carter and Lacy (2005), the first patient of SARS infection was informed in November 2002 in China. Five months after that WHO stated Guangzhou and Hong Kong as high-risk tourist destinations, followed by Beijing, Hebei, Inner Mongolia, Shanxi, and Tianjin as epidemic areas, advised international visitors not to visit. A month after, the number of patients infected by SARS amplified quickly in Beijing and expanded to the northern part of China. The effect of SARS on the economy of China was extreme. The GDP growth was the lowest since 1992 for the second quarter, falling from $9.9 \%$ to $6.7 \%$. The SARS epidemic affected the tourism industry in China, where the airline passengers declining nearly $50 \%$ and passenger transportation declined by 23.9\% (Zeng, Carter \& Lacy, 2005).

The SARS outbreak also shocked the Southeast Asian travel. The World Travel and Tourism Council (WTTC, 2003) estimated the number of people in tourism industry lost their jobs up to three million people in the area severely affected in China, Hong Kong, Singapore and Vietnam. The cost of outbreak for these four countries reached over than USD20 billion and impacted their GDP (McKercher \& Chon, 2004). Number of passengers to Asia Pacific countries declined from 10\% to 50\% in end of March to April 2003 (Abdullah et al., 2004), and fell by $70 \%$ or more across the rest of Asia in 2003 (McKercher \& Chon, 2004). Tourist arrivals to Hong Kong dropped by $64.8 \%$ and $67.9 \%$ during month of April and May, respectively, in the peak of SARS spreading (Abdullah et al., 2004). Countries that experienced a dip in tourist arrivals from China included Malaysia and Indonesia that imposed one week travel restriction for tourist from China, Vietnam, as well as Taiwan. The authority lifted the restriction a week later because China and Vietnam compulsory to obtain medical credentials mentioned they were SARS-free. Malaysia's tourism industry was the biggest hit from the 2003 SARS outbreak, because tourism is the third income after palm oil and manufacturing. The total number of tourists from all countries to Malaysia fell by $20.5 \%$ in 2003 to 10.57 million compared to 13.31 million the year before. The tourist arrivals from China also fell by 37.3\% compared to 2002 ("How SARS impacted tourism," 2020).

\section{Justification For This Study}

The earliest case of SARS was in November 2002, officially reported in Asia in February 2003, and four months later, the country stated the last cases. During that period, the total cases reported was 8,098. According to Llyod-Jones (2020) 7,324 people recovered and 774 died. While WHO recorded that SARS affected 26 countries ("SARS, n.d.), the US Center for Disease Control and Prevention ("SARS 10 years after," 2020) claimed 29 countries were affected, and Lloyd-Jones (2020) reported that SARS shown in 37 countries. The highest number of cases were in Mainland China at 5,327 and Hong Kong 1,755 with deaths 349 and 299 respectively. Taiwan was third with 346 cases and 37 deaths, followed by Canada (principally the Toronto area) with 251 cases and 43 deaths, and Singapore, 238 cases and 14 deaths. Vietnam was sixth with 63 cases and 5 deaths, Philippines, 14 cases and 7 deaths and all other countries totaled 104 cases and 25 deaths (Lloyd-Jones, 2020). Only eight people were infected in US and none of them died. By July 5, Taiwan, was the last area with recent local transmission. Although WHO declared SARS outbreaks had been contained worldwide, the people should remain alert (Wilder-Smith, 2020). 
Although Covid-19 and SARS started around of November of 2019 and 2002 respectively, SARS was over by end of June 2003 while Covid-19 continues to ravage nations beyond June. infecting and re-infecting people and turning nations and regions into epicenters of the contagious disease (Fu, 2020). While SARS had spread to 26 countries ("SARS," n.d.) and contained worldwide by July 5, 2003 (Wilder-Smith, 2005) with a total of 8,098 cases and 774 deaths (Lloyd-Jones, 2020), Covid-19 has spread to 216 countries, areas and territories with 12,322,395 confirmed cases and 556,335 confirmed deaths by July 10, 2020 ("Coronavirus disease (Covid-19) pandemic," n.d.). The United Nations advise UN personnel to balance the criticality of their proposed itinerary or meetings due to uncertain situation along the pandemic (Advice for Travelers, n.d.). While many countries advise their people against non-essential travel, the WHO does not advise against travel but cautions individuals planning travel should seek advice the best way to protect themselves. The WHO states that the travelers him or herself that should understand the risk of being infected during travelling and do the best not to infect others (“Travel Precautions," 2020).

The IATA provides a COVID-19 travel regulations map that shows most countries are "totally restrictive," several are "partially restrictive," and very few "not restrictive." Even the "not restrictive" require screening upon arrival and evidence of medical insurance, and some impose a quarantine period. With the fear of the invisible virus aboard the aircraft without social distancing in seat arrangement, and the various travel restrictions and quarantines imposed by the different countries, the airlines industry can expect to have fewer flights and lower full passenger load until the WHO announces the end of the pandemic. Hence, there is an urgency to study the COVID-19's impact on the airlines industry to identify the implications for business and propose policy to mitigate the losses and manage the sustainability of the airline industry in the protracted pandemic without a foreseeable end at this time of writing.

\section{Methodology}

As the Covid-19 is a recent and evolving phenomenon, and the scope of study is the airline industry, the methodology relies on data from authoritative sources such as the World Health Organization (WHO) and International Civil Aviation Organization (ICAO), both specialized agencies of the United Nations, the International Air Transport Association (IATA), an association of all airlines in the world and business sources of information to identify the challenges of the airline industry. Peer reviewed research findings on past pandemics, especially the Severe Acute Respiratory Syndrome (SARS) in 2002-2003 that also started from China to help propose recommendations to manage sustainability of the airline industry.

\section{Implications For Airline Business}

\section{Financial Crisis}

Covid-19 has impacted the airlines industry as governments implement travel restrictions to foreign destinations or cities within the country. Table 1 shows the passenger load factor of international flights by region from January to March 2020. February showed a decline by an average of $-5 \%$ over January, with Asia Pacific hardest hit at $-13.7 \%$ and Europe least affected at $-0.7 \%$. In March, all regions recorded a steeper decline over February at an average of $-12.1 \%$ except Africa below -5\% and Asia Pacific improved to -10.8\%. Comparing between January and March, Asia Pacific suffered the highest loss in passenger load factor by $-24.5 \%$ followed by North America at $-18.9 \%$ and Middle East $-18.4 \%$.

Table 1: Passenger Load Factor on International Flights January to March 2020 by Region

\begin{tabular}{|l|l|l|l|l|l|l|}
\hline Region & Jan & Feb & Feb vs. Jan & Mar & Mar vs. Feb & Mar vs. Jan \\
\hline Europe & 82.7 & 82 & -0.7 & 67.6 & -14.4 & -15.1 \\
\hline Latin America & 82.7 & 81.3 & -1.4 & 66.5 & -14.8 & -16.2 \\
\hline North America & 81.7 & 77.7 & -4 & 62.8 & -14.9 & -18.9 \\
\hline Africa & 70.5 & 65.7 & -4.8 & 60.8 & -4.9 & -9.7 \\
\hline Middle East & 78.3 & 72.6 & -5.7 & 59.9 & -12.7 & -18.4 \\
\hline Asia Pacific & 81.6 & 67.9 & -13.7 & 57.1 & -10.8 & -24.5 \\
\hline Average & 79.6 & 74.5 & -5.05 & 62.5 & -12.1 & -17.1 \\
\hline
\end{tabular}

Source: Adapted from Statista, Passenger load factor (PLF) on international flights from January to March 2020, by region

The International Civil Aviation Organization (ICAO, 2020) estimated the passenger revenue loss from January to May 2002 at approximately USD126 billion, with Asia Pacific leading by USD48 billion followed by 
Europe USD30 billion, North America USD28 billion, Latin America USD8 billion, Middle East USD7 billon and Africa USD4 billion.

The International Air Transport Association (IATA, 2020) projects a 54.7\% decline of revenue passenger kilometers (RPKs) of both international and domestic travel in 2020 compared to 2019. Originally the ICAO forecasted the world scheduled passenger traffic for 2020 compared to baseline should result in generally reduction of 42 to $52 \%$ of airline seats, loss in 2,344 to 2,978 million passengers and a possibly loss of gross operating revenues of USD308 to 391 billion. This is like a decrease from $62 \%$ to $48 \%$ overall of both international and domestic passengers, comparing 2020 from 2019.

The estimate for international passenger traffic for 2020 compared to baseline is an overall reduction of 55$67 \%$ of airline seats, decrease by 1,196 to 1,456 million passengers and USD 208 to 256 billion loss in gross operating revenues of airlines. The estimate for domestic passenger traffic for 2020 compared to baseline is an overall reduction ranging from 32 to $42 \%$ of airline seats, decrease by 1,148 to 1,522 million passengers, and USD 101 to 135 billion loss of gross operating revenues. Table 2 shows the estimated impact on international and domestic passenger traffic and revenues by region for 2020 compared to baseline (ICAO, 2020).

Table 2: Estimated impact on international and domestic passenger traffic and revenues by region for 2020

\begin{tabular}{|l|l|l|l|l|l|l|}
\hline & \multicolumn{4}{|l}{ International Passengers } & \multicolumn{2}{l|}{ Domestic Passengers } \\
\cline { 2 - 7 } Country & Capacity $\%$ & $\begin{array}{l}\text { Passenger } \\
\text { million }\end{array}$ & $\begin{array}{l}\text { Revenue } \\
\text { USD billion }\end{array}$ & Capacity \% & $\begin{array}{l}\text { Passenger } \\
\text { million }\end{array}$ & $\begin{array}{l}\text { Revenue } \\
\text { USD billion }\end{array}$ \\
\hline Europe & -68 & -681 & -92 & -47 & -177 & -14 \\
\hline Latin America & -62 & 83 & -17 & -55 & -147 & -12 \\
\hline North America & -66 & -116 & -31 & -40 & -513 & -60 \\
\hline Africa & -68 & -61 & -13 & -59.0 & -29 & -3 \\
\hline Middle East & -65 & -116 & -21 & -53 & -25 & -2 \\
\hline Asia Pacific & -67 & -397 & -82 & -38 & -631 & -44 \\
\hline
\end{tabular}

Source: Adapted from "Effects of Novel Coronavirus (COVID-19) on Civil Aviation: Economic Impact Analysis," by Air Transport Bureau, International Civil Aviation Organization, June 22, 2020. The figures indicate the upper end of the estimate.

\section{Bankruptcy}

The travel demand to Asia plummeted when the news of the virus became widespread in late January 2020 . Airlines radically cut flights to China, and other locations in Asia as Covid-19 led passengers to cancel travelling to the region. Within weeks, as the virus spread to Europe, followed by the Americas and Africa, passenger demand plummeted across the board. People were avoiding travel with airlines, starting to avoid close proximity to other people, afraid that other people might be carrying the virus. People delayed buying tickets for future travel, due to the uncertainty surrounding the outbreak (Slotnick, 2020).

The depressed economy forced Thai Airways International to file for bankruptcy reporting losses of 18 billion baht (US\$564 million) in the first half of 2020 due to the pandemic that has closed the country to international flights until June 30, and on May 19, 2020 the Thai government approved the plan to offer a state bailout of the Covid-19 grounded airline (Janssen, 2020).

Slotnick (2020) documented some of the companies that have crumpled, declared insolvency, or adjourned operations due to Covid-19 are as follows:

- $\quad$ Flybe (UK): A British regional airline that operated about $40 \%$ of domestic flights in the UK, Flybe ran out of cash and declared bankruptcy on Thursday, March 5.

- Trans States Airlines (US): A Missouri-based regional airline, Trans States plans to consolidate operations with ExpressJet Airlines - both United's regional carriers.

- $\quad$ Compass Airlines (US): A regional carrier for American Airlines, and owned by Trans States Holdings, Compass shut down in April as American had to cut capacity by $80 \%$ by May and thus, has less of demand for contract airlines.

- Virgin Australia (Australia): Virgin Australia entered "voluntary administration," the Australian equivalent of Chapter 11 bankruptcy, on Tuesday, April 21.

- Avianca (Colombia): One of Latin America's largest and oldest airlines, Avianca filed for Chapter 11 bankruptcy in May. 
This happens because when the aircrafts do not fly, their fixed costs still applied. The following are the fix costs examples from different airlines or groups : Lufthansa: 1.03 billion euros: Air France-KLM: €907 million; IAG: €886 million; EasyJet: €295 million; Ryanair: €235 million, and Wizz Air: €97 million. Aggravating the situation, many airlines have limited financial reserves : Ryanair: 15.9 months; Wizz Air: 15.4 months; EasyJet: 8 months; IAG: 6.5 months; Air France - KLM: 3.6 months, and Lufthansa: 3 months (Fauvelle, 2020). It would seem that the budget airlines are better prepared to weather the crisis compared to the traditional national airlines.

\section{Unemployment}

The ban on travel has a significant effect on aviation jobs. The Trump administration's 30-day ban effective March 14, 2020 on most travelers from Continental Europe because of Covid-19 caused Norwegian airlines to temporarily halve its staff (Chokshi, 2020). American carrier, Delta considered trimming international schedules by $40 \%$, up from a $25 \%$ reduction before the ban. Europe's biggest carrier, Germany's Lufthansa cut flights in half for April and considered trimming schedules by $90 \%$ as more countries impose travel ban. Airlines that serve small domestic markets and rely on global interconnections face the prospect of shutting down (The Economist, 2020, March 15).

On April 7, the IATA (2020) projected 25 million jobs were at risk with plunging demand for air voyage. Globally, around 65.5 million people's livelihoods depend on the aviation industry, including travel and tourism sectors. In a scenario of harsh travel restrictions lasting for the next three months, the IATA research showed the potential loss of jobs by regions were 11.2 million in Asia-Pacific, 5.6 million in Europe, 2.9 million in Latin America, 2.0 million in North America, 2.0 million in Africa, and 0.9 million in the Middle East.

Table 3: Covid-19 potential impact on Asia-Pacific aviation job losses

\begin{tabular}{|c|c|c|c|c|}
\hline Country & $\begin{array}{c}\% \text { change in } \\
\text { passenger demand } \\
(2020 \text { vs } 2019)\end{array}$ & $\begin{array}{l}\text { Passenger demand } \\
\text { impact (origin- } \\
\text { destination volumes } \\
2020 \text { vs 2019) }\end{array}$ & $\begin{array}{c}\text { Revenue } \\
\text { impact (US\$, } \\
\text { millions 2020 vs } \\
\text { 2019) }\end{array}$ & $\begin{array}{r}\text { Potential } \\
\text { jobs impact }\end{array}$ \\
\hline 1. India & $-47 \%$ & $-89,764,000$ & $-11,221$ & - \\
\hline 2. Thailand & $-52 \%$ & $-55,562,000$ & $-8,289$ & - \\
\hline 3. Indonesia & $-49 \%$ & $-59,756,000$ & $-8,225$ & - \\
\hline 4. Vietnam & $-45 \%$ & $-31,902,000$ & $-4,347$ & $-989,500$ \\
\hline 5. Cambodia & $-45 \%$ & $-5,390,000$ & -866 & $-770,000$ \\
\hline 6. Japan & $-50 \%$ & $-93,862,000$ & $-22,625$ & $-585,900$ \\
\hline 7. Philippines & $-47 \%$ & $-28,852,000$ & $-4,481$ & $-548,300$ \\
\hline 8. Sri Lanka & $-58 \%$ & $-4,049,000$ & -715 & $-408,200$ \\
\hline 9. Korea & $-52 \%$ & $-59,219,000$ & $-10,755$ & $-371,200$ \\
\hline 10. Australia & $-51 \%$ & $-50,510,000$ & $-14,255$ & $-362,100$ \\
\hline 11. Pakistan & $-52 \%$ & $-9,866,000$ & $-1,829$ & $-259,400$ \\
\hline 12. Myanmar & $-48 \%$ & $-4,377,000$ & -691 & $-245,200$ \\
\hline 13. Nepal & $-51 \%$ & $-3,422,000$ & -522 & $-229,900$ \\
\hline 14. Malaysia & $-51 \%$ & $-33,513,000$ & $-4,236$ & $-220,500$ \\
\hline 15. New Zealand & $-50 \%$ & $-12,865,000$ & $-3,388$ & $-170,100$ \\
\hline 16. Singapore & $-48 \%$ & $-23,897,000$ & $-6,732$ & $-169,000$ \\
\hline 17. Fiji & $-51 \%$ & $-1,158,000$ & -305 & $-65,100$ \\
\hline 18. Bangladesh & $-48 \%$ & $-5,541,000$ & $-1,073$ & $-61,900$ \\
\hline 19. Maldives & $-51 \%$ & $-2,747,000$ & -639 & $-37,200$ \\
\hline 20. Laos & $-51 \%$ & $-1,618,000$ & -220 & $-23,800$ \\
\hline 21. Brunei & $-50 \%$ & $-605,000$ & -114 & $-8,500$ \\
\hline
\end{tabular}

Source: AITA (Apr 24, 2020). Covid-19 Impact on Asia-Pacific Aviation Worsens. Note: Data has been sorted 


\section{Travel Restrictions}

As Covid-19 spread from Wuhan to the rest of China and other countries by early 2020, travelers canceled air tickets and asked for refunds. By February 26, US President Donald Trump considered restricting travel to Italy, South Korea, and other affected (Mason, 2020) but was criticized as a discriminative measure that would not halt the spread of the virus. Israel, Mongolia and El-Salvador were among the first to ban entry of foreign travelers. Israel ordered self-quarantine for travelers from five European countries from March 6 (TOI Staff, 2020). Mongolia closed its borders to China on January 27. By March 11, Mongolia (Wilson, 2020) and El Salvador (McDonald, 2020) barred the entry of foreigners (McDonald, 2020). Governments repatriated overseas employees and required their students studying abroad to return home before the lock down, such as the case of Singapore (Wong, 2020).

Almost immediately after WHO announced Covid-19 a pandemic, countries around the world imposed partial or total lockdown and banned all travelers or travelers from countries with a high degree of the communicable disease. Residents and citizens who violate the quarantine and self-isolation to travel abroad or other cities within the country face fines, criminal charges and imprisonment (Cachero, 2020). Canada joined the growing list of countries that imposed self-isolation of 14 days for travelers and citizens upon landing at the airport (Russell, 2020). In Muslim dominant countries such as Malaysia, movement control order helped also to prevent religious gatherings and conferences, venues that resulted in the first multiple cases of Covid-19 (Yi, 2020; Kong, 2020) while Saudi Arabia canceled Haj 2020 that annually brought 2.5 million international visitors (Chitwood, 2020), resulting in an estimated loss of USD4.6 billion (Bostock, 2020). Although Saudi Arabia has now allowed local pilgrims. The country has 272,950 cases and 2.816 deaths as at July 30 (Saudi Arabia, 2020).

Alexandre De Juniac, Director General and Chief Executive Officer of the IATA (IATA, 2020) initially thought the gloomy scenario was a revenue loss of $\$ 113$ billion but as governments around the world imposed a blanket of restrictions, he estimated that if the travel restrictions continued into June, a 38\% decrease in global demand and a $\$ 252$ billion loss of customer revenue can be expected, that is, $44 \%$ down on 2019 . Countries that depend on tourism as an important source of revenue were badly affected, for example, Covid-19 is estimated to cause the air transport industry in Italy an estimated loss of revenue by 25 to 55\% in 2020 (Statista, 2020, May 11).

Table 4 shows the ten countries whose people travel the most (Sheth, 2019). Finland tops the list with an average total of 7.5 trips per person and followed by the United States at 6.7 trips. While the rest of countries are higher in domestic trips per person, Hong Kong is highest in outbound trips at 4.3, followed by Norway at 2 . On April 14, the IATA (2020) estimated that the aircraft traveler income will decline by US\$314 billion in 2020, a $55 \%$ decrease contrasted with 2019, and carriers in the Asia Pacific would see the biggest income drop by US\$113 billion, an estimated loss of US88 billion in 2020 compared with 2019.

The Economist and YouGov's (2020) March poll showed 50\% of US adults had cancelled travel plans in response to the Covid-19 which not only affects the airline industry but also its associated businesses, such as airport retail and dining as well as hotels and tours. Chief Executive Officer of Airport Operators Association, Karen Dee on April 15, 2020 said that the impact of Covid-19 resulted in many airports experiencing zero or nearzero passengers. Nevertheless, airports have to continue to continue open for critical services, such as return flights and the increased number of full-freight airlifts, but also air ambulances, HM Coastguard, military flights, life-line services to isolated populations, flying crew out to the oil and gas rigs in the North Sea and supporting maintenance of offshore wind. While airfields are struggling to play their part to serve peoples, their key source of income vanishes. 
Table 4:Countries Whose People Travel the Most.

\begin{tabular}{|c|c|c|c|c|}
\hline Rank & Country & $\begin{array}{l}\text { Outbound Trips } \\
\text { (average trips per } \\
\text { person per year) }\end{array}$ & $\begin{array}{l}\text { Domestic Trips (average } \\
\text { trips per person per } \\
\text { year) }\end{array}$ & $\begin{array}{l}\text { Total Trips (average } \\
\text { trips per person per } \\
\text { year) }\end{array}$ \\
\hline 1 & Finland & 1.70 & 5.80 & 7.50 \\
\hline 2 & $\begin{array}{l}\text { United } \\
\text { States }\end{array}$ & 0.20 & 6.50 & 6.70 \\
\hline 3 & Sweden & 1.50 & 4.40 & 6.00 \\
\hline 4 & Denmark & 1.40 & 3.90 & 5.30 \\
\hline 5 & Norway & 2.00 & 3.20 & 5.20 \\
\hline 6 & $\begin{array}{l}\text { Hong } \\
\text { Kong }\end{array}$ & 4.30 & 0.03 & 4.30 \\
\hline 7 & $\begin{array}{l}\text { New } \\
\text { Zealand }\end{array}$ & 0.50 & 3.80 & 4.30 \\
\hline 8 & Canada & 1.00 & 3.20 & 4.10 \\
\hline 9 & Australia & 0.40 & 3.40 & 3.80 \\
\hline 10 & France & 0.40 & 3.10 & 3.50 \\
\hline
\end{tabular}

Source: Sheth, K. (2019, March 15). Countries That Travel the Most. World Atlas. Retrieved from https://www.worldatlas.com/articles/countries-whose-citizens-travel-the-most.html

\section{Customer Distrust}

In 2010, the WHO that spread of infection may occur between passengers seated closed to each other, usually because of the sick individual coughing or sneezing or by touch, and this direct contact was difficult to avoid (WHO, 2010 p. 22). At the University of Chicago Medicine, the hospital's procedures for influenza define contact as within six feet of an infected person for 10 minutes or more. Breathing illnesses can increase through the surfaces such as airplane seats and plate tables (McKeever, 2020).

Despite the assurance of safety measures, 27 years old female passenger, Chen Moumou was tested positive for Covid-19 on arrival in Guangzhou, China on March 25. Chen had flown with China's Spring Airlines on March 24 and no nucleic acid tests were performed as her temperature was normal before boarding in Phnom Penh, Cambodia. A health declaration was made on entry without discomfort, and she was taken to an isolation hotel for observation. Although her body temperature was normal, the results for Covid-19 test came out positive. Chen's case brought the number of passengers who left Cambodia and tested positive in China to eight since the outbreak started in January (Khymer Times, 2020, March 27). Such cases increase the distrust of customers towards air travel for fear of infection on board.

As at April 26, 2020, 15 US flight attendants died in nine days linked to Covid-19 (Feldman, 2020). While major carriers allowed passengers to switch seats to assist with social separation, they did not require passengers to use shields or stay six feet away, prompting the Association of Flight Attendants (AFA) to call on the Department of Transportation, and also with the Department of Health and Human Services, to "end all leisure travel until the virus is contained" as 250 flight attendants had tested positive for Covid-19 and some died as a result while others asked themselves if they were "helping to spread the virus" (Bloom, 2020).

The Airports Council International (ACI, 2020) estimates a cost of over 50\% of traveler traffic and 57\% or over USD 97 billion airport revenues in 2020 compared to commercial as usual. Airport authorities have implemented safety measures for passengers and employees. Hong Kong's Airport Authority is the first to provide Clean Tech, including full-body sterilisation cubicles, antimicrobial coating for high-touch surfaces, and spring-cleaning robots, at the Hong Kong International Airport since May 4, 2020. Passengers and staff, following a temperature check, are required to enter the enclosed booths for a 40 -second disinfection procedure. Intelligent Sterilization Robots with UV light and air sterilisers to sterilise up to $99.99 \%$ of bacteria on surfaces 
and in surrounding air within 10 minutes are used around the clock in community toilets and main functioning spaces in the terminal building (Fox, 2020).

People who have or wish to travel have to incur additional expenses with carrying sufficient personal protection items such as masks and sanitizers. The Transportation Security Administration of USA allows passengers to carry 12 ounces of hand sanitizer and advises passengers to wear a face covering during the screening process, remove food items from carry-on bags and place them in the bin for screening, wash hands before and after completing the security screening process and maintain a social distance of six feet wherever possible, (TSA, 2020).

The JetBlue airline has been reported to be the first to require passengers wear a face-covering during the flight, not just to protect oneself but also all passengers on the airplane (Wallace \& Rokus, 2020). The Emirates Airlines in coordination with Dubai Health Authority on April 15, 2020 became the first airline to establish on-site rapid Covid-19 tests for passengers with outcomes within 10 minutes (Cripps, 2020).

Despite these safety measures. people are still afraid to travel for fear of being infected by Covid-19 and the self-quarantine of 28 days with 14 upon arrival at country of destination and 14 upon arriving in home country. With the Covid-19 crisis expected to extend over the next two to three years until an effective vaccine is found, the passenger airline industry will need to find ways to revive confidence in air travel.

\section{Travel Retail}

The Covid-19 also affects tourism and trade. A decrease in international travel receipts to a range between USD 910 to 1,170 billion in 2020 is projected related to the USD 1.5 trillion produced in 2019 , with $100 \%$ of international destinations having travel limitations (UNWTO, 2020). The trade of global merchandise volume is expected to decline between $13 \%$ and $32 \%$ in 2020 compared to 2019 (WTO, 2020). One of the merchandise products associated with the airline industry that has been badly hit is travel retail. Travel retail completes the air travel experience with providing the ambience and convenience of duty-free shopping while waiting for flight departure.

The duty-free shops at the airport are another casualty of Covid-19. The Dufry Group, a Swiss-based retailer which runs duty-free, duty-paid and convenience stores in 63 countries acknowledged a $70 \%$ revenue decline as the worst-case scenario for 2020 (Pentol, 2020). Swiss research agency M1nd-set surveyed 1,500 airline passengers in April found a significant majority (62\%) keep away from contact with sales staff when in the shops and over half just look at and not relishing products (Bates, 2020). On the other hand, the online duty-free services are not familiar among tourists, and sellers and other airport commercial associates will need to assess their digital approach and renew efforts to offer a more forceful omni-channel presence to hold loyal shoppers and convert non-shopper travellers.

Although online shopping has increased dramatically, marketing intelligence firm Stackline study ecommerce across the U.S. comparing 2020 and 2019 performance and found travel related goods among the top 10 fastest declining led by luggage and briefcases both $-77 \%$, cameras $-64 \%$, and apparel averaging $-62 \%$, sports related (rash guards, boy's athletic shoes and gym bags) -58\% (Jones, 2020)

Samsonite, one of the world's largest suitcase producers with over a century's history, earned US\$3.64 billion in 2019 but worldwide travel restrictions have caused the net global sales to plunge by 80 percent (Stockdill, 2020) and first-quarter loss of US\$787 million (Moon. 2020). Luggage startup Away, a trendy suitcase brand, is forced to lay off over half its workforce as the Covid-19 caused global travel ban had resulted in $90 \%$ decline in sales (Howland, 2020).

The IMF and World Bank (2020) have projected $-3 \%$ to $-5.2 \%$ contraction in world GDP in 2020, even worse than during the 2008-09 financial crisis. The extent of the impact of Covid-19 on the airline industry, tourism, trade, and economy depends on the extent and scale of the epidemic, restraint events, the degree of customer selfconfidence for air travel and economic circumstances among other issues.

\section{Policy Recommendations.}

\section{Positioning: Customer Safety First}

The airline industry, as a sector, has to be ready for all eventualities given the uncertainty of how long the COVID-19 epidemic will end, or how quickly economies will rebound from their lockdowns. Oxford Economics (2020) estimates the economic impact of Covid-19 on travel losses at a \$355B deficit, forcing sellers to move significances in their marketing policies (Goodway Group, 2020). Airlines may have to consider positioning or repositioning to build trust in their brands in a pandemic. 
Brand positioning is intending the firm's proposing and image to reside in a top of mind of the objective market (Kotler \& Armstrong, 2020). Companies may ponder moving a merchandise due to deteriorating performance or due to major changes in the environment (Shafiee et al., 2014). However, all airlines suffer declining performance in the current pandemic and repositioning may risk losing brand value. The Singapore Airlines has maintained its slogan "A Great Way to Fly" since it was founded in 1972 and strived constantly to provide the state-of-the-art aircraft, good food and great service. The Emirates Airlines has changed slogans from "The Finest in the Sky" to "Fly Better" to challenge competitors such as Singapore Airlines. Each year, Forbes announces the Airline Excellence Awards based on key aspects including operational safety, passenger evaluations, profitability, investment rating, fleet age, and item offerings such as best economy on long-haul flights and seating selections in other types. For 2020, among the winners were Best First Class: Singapore Airlines, Best Business Class: Qatar Airways and Best Premium Economy: Air New Zealand (Rosen, 2019).

Pre Covid-19, customers may respond to the airlines' slogans and global excellence awards. Once Covid-19 started, protection from the virus has become top priority from waiting at the airport to their journey in the aircraft. Customers expect airports to apply technology that rival the Hong Kong airport's full-body disinfection booths and cleaning robots, or Emirates on-site Covid-19 test results within 10 minutes so passengers are more assured of a virus-free journey rather than being tested positive upon arrival at foreign airports (Horton $\left.{ }^{2}, 2020\right)$.

\section{Aircraft}

While many airports adopted safety innovations such as cleaning and air-purifying robots, airlines have yet to announce innovations except the high efficiency particulate air (HEPA) filters that were fitted because of the SARS pandemic. American, Delta, United, Southwest and JetBlue claim their coronavirus cleansing procedures exceed the Centre for Diseases and Control (CDC) requirements. Some airlines claim they deep clean nightly that happen only once a month under normal conditions as it takes up to 7 hours. They claim to use hospital-grade EPA-certified sterilisers in the toilet, cabin, and flight floor during the nightly clean which includes wiping seat trays, seatback pockets, seats, and floors. Inbound linens or headphones from affected countries are sanitized disjointedly from other accessories. In some cases, the airline discards the objects as a precaution (Whitmore, 2020)

The US airlines use alerts from CDC to stock planes with additional sanitary supplies, when arriving to a terminus with a Level 2 or higher recommendation, that may include gloves, masks, alcohol-based hand sanitize, sani-com wipes, foaming hand soap, disinfectant wipes, mini-mops with a handle, trash pickup devices, and on trans-Pacific flights, travellers might receive convenience kits with hand sanitizer or disinfectant towels. In response to previous virus outbreaks, most aircrafts now utilize a HEPA filter for the cabins to remove up to $99.7 \%$ of floating particles (Whitmore, 2020).

JetBlue airline is reportedly the first to require passengers to wear a face-covering during the flight (Wallace \& Rokus, 2020). American Airlines has removed a passenger from a flight who refused to wear a face cover (Coronavirus: American Airlines passenger removed for not wearing mask, n.d.).

\section{Social Distancing}

While Lufthansa ended social distancing in May with mandatory face masks (Boon, 2020), the decision by Air Canada and WestJet to relax on-board physical distancing policies from July was criticized by those who worry about the health implications amid the COVID-19 pandemic (Jones, 2020). American and United airlines would book flights to full capacity from July (Koenig, 2020) and other US airlines would be announcing the end of social distancing on board with varying deadlines in the second half of 2020 (Gilbertson, 2020).

As social distancing in the aircraft is a customer's top concern, aerospace designer-manufacturer called Safran and Universal Movement that produces transportation technology proposed partitions with a bowed design over the middle seat that splits people sitting in the corridor and window (Fox, 2020). Italian aircraft interiormanufacturer Avio interiors designed a "Glassafe" bubble with a clear cocoon that assigns to the top of current airplane chairs, making an secluded volume around the passenger to evade contact and interface via air between passengers (Rizzo, 2020). US-based startup zephyr aerospace introduced an economy class zephyr seat and bed combination, with a choice of upper or lower deck that can retrofit existing Boeing and Airbus commercial aircrafts, for airlines that target travelers who value privacy and willing to pay extra for the ability to sleep (Street, 2020).

\section{Customer Engagement: Regular and Responsive}

At the start of the pandemic, passengers received little or no information from their airlines on the status of the flight they booked. Mobile messaging channels such as email, social media and texting can speed up updates to maintain customer trust and loyalty. Clear, translucent and timely communications with all relevant stakeholders 
are important when making a platform to redesign the business with relevant stakeholders (Basnayake, Mack \& Tong, 2020).

Customers. If promised obligations cannot be achieved due to a distraction, it is essential for airlines to sustain open lines of message to mitigate punitive damages or liabilities associated with disrupted customer obligations. The Forbes magazine received complaints about airlines refusing to refund tickets even if it was the airlines that initiated cancellation. The US Department of Transportation (DOT) mandates a reimbursement if the airline annuls a flight or makes a "significant schedule change" that includes non-stop trips that are rebooked as networks or changes more than two hours from the original flight time. The DOT published a clarification on April 3 and a follow-up on May 12 to remind airlinesto provide recompences, plus the ticket price and any possible fee indicted for facilities a passenger is incompetent to practice, even if the flight disruptions were outside of the carrier's control (Adams, 2020).

Global carriers such as Singapore Airlines, Cathay Pacific and Lufthansa provide comprehensive safety information for pre, during and post flight information - explaining mobile check-in and contactless boarding, procedures for group boarding and mandatory face-covering, assuring cabin sanitization after each flight and the use of HEPA filters to remove bacteria, to reminding social distancing when disembarking as well as entry and departure requirements of destination (\#WeCare - so you can fly with no worries, n.d.). Information including seat assignments and capped capacity, virtual check-in, removal of backseat magazines and entertainment tablets, sealed and single-serve refreshments, temperature checks, and wipes and masks provided or not-provided are provided by airlines such as Air Canada and United Airlines (Cochran, 2020).

Employees. From check-in to boarding to in-flight, communication with employees seek to stabilize between cautiousness and preserving a business-as-usual mind.

Suppliers. Airlines must conserve contact with providers that also capable to deliver goods and services during COVID-19 pandemic and their regaining plans, so they can consider alternate supply chain selections in short notice.

Creditors and investors. Many airlines have low reserves that may not last an extended period of travel restrictions. A review of lend agreements to identify sensitive debts and avoid dynamic technical debt breaks would show if airlines are proactively managing the dialogue with creditors concerning any necessary modifications.

Government and regulators. The airlines should seek advice from legal teams on possible obligations and from their business units concerning how to manage communications about continuing breaches and pool of proof, if any.

\section{Pricing Strategy: Target Market and Travel Partners}

Following the 9/11 attack in 2001 and the 2008 recession, passenger traffic did not return to pre-incidence level until 5 years later (Mariano, 2020). This suggests airlines marketers have to employ promotional strategies to stimulate purchase simultaneous with positioning their brand as prioritizing customer safety first.

Chinese airlines offered low fares to restore seat capacity, for example, if we fly from Shanghai to Chengdu on Juneyao Airlines using one-way direct trip, it only cost 90 yuan (\$13) plus 50 yuan in taxes, a three-and-a-half hour journey, about the same as a flight from New York to New Orleans (Suhartono, 2020). If prices are lower after the pandemic along with customer safety first measures, passenger traffic may pick up faster to help restore profitability.

On the contrary, if airlines are charging customers more for a flight, it may create a negative association with the airlines. US carrier Frontier Airlines announced on May 4 a "more room" fee from US\$39 purchasable for flights between May 8 and August 31 to guarantee an empty middle seat but by May 6, the airline rescinded the offer due to criticism from members of the United States Congress (Drescher, 2020). If airlines are in a hurry to raise airfare to cover losses, then the aviation industry may take a longer time to recover to pre-crisis performance.

In a March 2020 survey, Global Web Index found the top five factors for UK and US customers to book travel during the coronavirus outbreak were travel assurance procedure that covered damage caused by the virus, flight discounts, suppleness, accommodation discounts and taking a domestic trip instead. The survey also showed that Gen Z scored the highest in all five factors over Millennials, Gen X and Baby Boomers (Global Web Index, 2020). 
Table 5: Factors that for people to book travel during the coronavirus outbreak

\begin{tabular}{|c|c|c|c|c|c|c|}
\hline & $\begin{array}{l}N \\
\mathbb{0} \\
0 \\
0\end{array}$ & 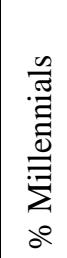 & $\begin{array}{l}x \\
\tilde{D} \\
\tilde{D} \\
\delta^{\circ}\end{array}$ & 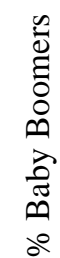 & 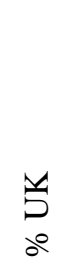 & $\begin{array}{l}\mathscr{D} \\
\delta^{\circ}\end{array}$ \\
\hline Travel insurance policy covers disruption caused by the virus & 30 & 16 & 12 & 17 & 17 & 20 \\
\hline Flight discounts & 26 & 27 & 14 & 17 & 15 & 20 \\
\hline Flexibility & 17 & 15 & 12 & 16 & 14 & 16 \\
\hline Accommodation discounts & 19 & 15 & 11 & 12 & 13 & 16 \\
\hline Taking a domestic trip & 17 & 15 & 11 & 12 & 13 & 16 \\
\hline If situation worsens domestically & 12 & 13 & 11 & 12 & 13 & 8 \\
\hline No change fees & 14 & 14 & 9 & 8 & 11 & 14 \\
\hline Attraction discounts & 16 & 13 & 9 & 4 & 11 & 9 \\
\hline Being able to speak to an agent about safest or most effective travel plans & 16 & 13 & 9 & 4 & 11 & 9 \\
\hline Could not be persuaded to book a vacation during this time & 33 & 48 & 62 & 61 & 53 & 48 \\
\hline
\end{tabular}

Source: Global Web Index, March 2020. Survey among 1,628 (US) and 1,509 (UK) internet users aged 16-64.

Most travel insurance companies have rewritten policies to contain virus-related exclusions, leaving travelers to tolerate the total of any disruptions (Beard, 2020). However, Table 5 shows airlines could work with customer data in setting the price-value strategy. Gen $\mathrm{Z}$ and Millennials are more responsive than Gen X and Baby Boomers in all factors except "if the situation worsens domestically" and "no change fees." Airlines can target the " $47 \%$ of travelers with canceled trips" who plan to rebook domestically. Airlines can build an attractive package partnering domestic hotels and tours to target Gen $\mathrm{Z}$ and Millennials and flexible schedules and easy customer access to agents about the safest and most effective travel plans ("How Covid-19 is affecting is affecting travel and tourism," n.d.).

Learning from the SARS crisis, Tourism Prince George in Canada is shifting focus to domestic travel to lure more regional visitors once the COVID-19 threat subsides. The organization plans to work with local partners such as the Chamber of Commerce, Downtown Prince George, Northern British Columbia Tourism, College of New Caledonia, local media and to design a marketing strategy to target northern communities in British Columbia and Alberta (Clarke, 2020). Airlines such as Air Canada and WestJet could partner with local tourism bodies to offer an attractive vacation package.

The Emirates is the first airline to provide free insurance to customers without any separate registration from July 23 to October 31,2020 . Valid for 31 days, customers can declare up to $€ 150,000$ (US\$174,000) for medical and confine costs of $€ 100$ (US\$116) per day until 14 days and funeral and repatriation costs may be protected by the financial assistance program as well (Adriano, 2020)

Managing the supply chain effectively helps lower expenses that may contribute to offering better value to customers. At the beginning of Covid-19, supply chain obstacles were significant for firms doing business in China. As the virus spread worldwide, global airlines experienced operational disruption and changes in consumer behavior. Airlines may need to consider alternative supply chain options (e.g. masks, sanitizers, disinfectants, single-serve wares for food and beverages) if their suppliers are impacted by COVID-19. Alternative suppliers may offer competitive prices and provide temporary capacity to meet customer obligations (Basnayake, Mack and Tong, 2020).

\section{Government: Support and Collaboration}

Tew et al. (2008) cited global collaboration and cooperation as the most important lesson learned from SARS in strategic planning for destination marketers, which demands transparency to manage an epidemic or pandemic. Unfortunately, history has been repeated with the late news of the Covid-19 outbreak that caught most countries ill prepared except for a few countries such as Singapore, Hong Kong, Taiwan and South Korea that implemented immediate measures based on experience with SARS.

However, strong coordination must also take place on a national and municipal level. The city of Toronto and the Toronto Transit Commission liaised with a series of advertisements heartening Torontonians to become local 
tourist, using endorsers and influencers who encouraged Torontonians to take advantage of the city sights, restaurants, and accommodations. The subway system aired 20-second broadcasts every ten minutes. This collaborative and inclusive strategy helped to build trust with all stakeholder levels in the regaining planning between government and tourism industry (Tew et al., 2008).

Airlines should enhance their partnership and relationship with local and federal governments (IATA, 2015). Governments play a key role in determining the travel routes and which airlines to stop and start flying. Airlines should monitor government opportunities to promote local tourism as well as financial support for the aviation business.

\section{Rental}

The Federal Government of Canada waived ground agreement charges from March to December 2020 for the 21 airport authorities to support airports reduce cost pressures and preserve cash flow. The rental waiver provide aid up to \$331.4 million, reflecting payments in the same period of 2018 (Proteau, 2020).

\section{Payroll Support}

The US Payroll Support Program in April to distribute US\$25 billion to ten US passenger airlines, including the four largest, offered a split between $70 \%$ funding for airlines, and 30\% low-interest credits (Horton, 2020). Airlines accepting the aid cannot fired or put absence for workers until September 30, when the crisis may be over (Slotnick $\left.^{2}, 2020\right)$. In Canada, major Canadian airlines have tapped into Canada's income subsidy program to rehire thousands of laid-off workers but still need cash, loans and a suspension on taxes and fees, prompting a consumer group to voice that a taxpayer bailout should include banning airlines from compensating executive bonuses and requiring airlines to refund consumers for cancelled flights (Burke, 2020).

China's temporary social insurance contribution reductions and exemptions have helped to ease the burden on businesses. The US, UK, Japan and Singapore are introducing similar government policies, and airlines should monitor the availability of these programs to mitigate risks (Basnayake, Mack and Tong, 2020).

\section{Bailout}

The Thai Airways International filed for bankruptcy citing losses of 18 billion baht (US\$564 million) in the first half of 2020 due to the pandemic that stopped the airline from making international flights until June 30 . On May 19, the Prime Minister of Thailand approved a state bailout for Thai Airways (Janssen, 2020).

\section{Regulatory Updates}

Airlines should regularly check their government's websites for update on Covid-19 and the travel safety measures that airlines have to implement, as in the case of Canada: travel.gc.ca, the World Health Organization (WHO), the International Air Transport Association (IATA), and Public Health Agency of Canada.

\section{Lobbying}

The varying responses of nations to Covid-19 create disparities in safety and risk protocols that can affect negatively the global airlines from "discriminated" countries. China's incentive and penalty system mandates that if five passengers of an airline test positive for COVID-19 on a route to China, the airline will have to append the flight for a week and if ten passengers test positive, the airline will be suspended from that route for four weeks. Airlines that carry no Covid-19 positive passengers can increase flights on a route for three consecutive weeks. China's plans for an Australia-New Zealand "travel bubble" form the patchwork re-opening feared by IATA, preferring a standard method that is easier to monitor than managing every country's nuanced rules (Horton $\left.{ }^{2}, 2020\right)$.

Chinese and foreign airlines are keen to rise their passenger flights. Airlines from Qatar, South Korea and Turkey planned to serve multiple Chinese cities over the summer, higher than China's stipend of one weekly flight on just single route. U.S. Delta Air Lines and United Airlines challenged to have the same several daily flights across numerous routes, and the U.S. would prohibit Chinese airlines' traveller flights unless China reviewed its policy $\left(\right.$ Horton $\left.^{2}, 2020\right)$. Airlines may have to support their governments and IATA to lobby for an international standard than the selective pruning method by each country that may coalesce as a region to boycott global airlines from certain countries.

\section{Conclusion: Limitations And Future Research}

The business implications for the airline industry and the proposed policy recommendations discussed above can be summarized in Table 6. 
Table 6: Implications for Business and Policy

\begin{tabular}{|l|l|l|l|l|}
\hline Recommendations & $\begin{array}{l}\text { Financial } \\
\text { Crisis } \\
\text { Implications }\end{array}$ & $\begin{array}{l}\text { Travel } \\
\text { Restrictions }\end{array}$ & $\begin{array}{l}\text { Consumer } \\
\text { Distrust }\end{array}$ & Travel retail \\
\hline Positioning: Customer Safety First & Yes & Yes & Yes \\
\hline $\begin{array}{l}\text { Customer Engagement: Regular and } \\
\text { Responsive }\end{array}$ & Yes & Yes & Yes \\
\hline $\begin{array}{l}\text { Pricing Strategy; Target Market and } \\
\text { Travel Partners }\end{array}$ & Yes & Yes & Yes \\
\hline $\begin{array}{l}\text { Government: Support and Collaboration } \\
\text { Yes }\end{array}$ & Yes & & Yes \\
\hline
\end{tabular}

Source: created by the author of this paper

Referring to Table 6 , the recommendation to the airlines industry to position customer safety first will help influence customer brand preference for an airline that prioritizes the customer's safety in a pandemic with social distancing aboard the aircraft through seat arrangement or new seat designs that minimize contact with other passengers. Complimentary insurance for Covid-19 related medical coverage such as provided by the Emirates Airlines can shift preference to an airline that offers a complete safety package. This will help overcome customer distrust to resume air travel, alleviating the airline's financial crisis and helping the associated travel retail products regain sales.

Enhancing customer engagement requires regular and responsive communication to keep customers informed of safety procedures related to all aspects of the customer's trip from a pre-arrival checklist that may include personal protective masks and hand sanitizers, to contactless check-in to maintaining social distance while waiting, boarding and disembarking as well as Covid-19 related procedures upon arrival at the destination airport. All this in addition to keeping the customer updated on expected time of arrival or departure at specific gates and providing access to agents and airport staff would help deliver a positive experience with the airline. Customer engagement helps increase customer confidence to travel by air again, thereby helping improve the airline's financial situation and revive travel retail at the airport.

An attractive package with food, accommodation and sightseeing tours providing super value at an affordable price could draw targeted customers out of their shell of distrust to enjoy vacations, restoring revenue to the airline and travel retail industry. The value package has to be backed by superior customer service at every contact point starting from the airport to the aircraft to the partner hotels and tours personnel to deliver an enjoyable vacation experience.

Getting support and collaborating with the state or provincial and federal governments can help the airline and travel retail industries keep afloat and regain financial strength when the travel restrictions are lifted. Government support such as wage subsidy to continue employment of workers and partnering governments to promote local tourism can help small businesses flourish again. Partnering governments could help build strength in lobbying for reciprocal relationship with various nations to fly international routes again.

\section{Limitations}

Information related to the impact of Covid-19 on the airline industry may be changing by the hour. As the economy is relaunched by phases, increased cases of infected customers and personnel in the aviation business at each phase can cause a return to lockdown until the Covid-19 curve flattens anew. Data of projected losses may worsen if travel restrictions are extended or improve if the travel restrictions are removed, at least for domestic tourism.

The literature related to Covid-19 is still confined to medical issues and literature related to the airline industry is difficult to locate. Although there is research related to hotels and tourism during the SARS epidemic/pandemic, there is a lack of evidence in the study of the impact of a pandemic on the airline industry and similarly, a lack of research into the recommendations to help the airline industry restore to pre-SARS level. 


\section{Future Research}

A defined scope of study such as the local airline industry instead of the global airline industry may help uncover the strengths, weaknesses, opportunities and threats that face the local airline industry. This could lead to more tailored recommendations to help local airlines regain their pre-Covid performance.

An attitudinal study between airline employees and customers will help determine the extent of understanding or cognition of Covid-19, affection and conation or intention to fly again. Employees who are fearful may communicate fear to passengers and thus, reinforcing distrust instead of assuring customers to fly again. The study may help airlines design integrated marketing communications to target selective markets to induce a return to air travel.

Last but not the least, a comparative study between ethnic groups within a country or a comparative study of consumer perception towards air travel between countries can help respective airline marketers formulate marketing strategies to revive and regain the profitability of airlines to pre Covid-19 levels.

\section{References}

"Advice for Travelers" (n.d.). COVID-19 response. United Nations. Retrieved from https://www.un.org/en/coronavirus/un-managers-who-approve-travel-areas-ongoing-transmission-Covid-19

"How SARS impacted tourism." (2020, Jan 29). The Star. Retrieved from https://www.thestar.com.my/news/nation/2020/01/29/how-sars-impacted-tourism

“Travel Precautions" (2020. April 28). World Health Organization. Retrieved from https://www.who.int/news$\mathrm{room} / \mathrm{q}$-a-detail/travel-precautions

Abdullah, A. S., Thomas, G. N., McGhee, S. M., \& Morisky, D. E. (2004). Impact of severe acute respiratory syndrome (SARS) on travel and population mobility: implications for travel medicine practitioners. Journal of travel medicine, 11(2), 107-111. https://doi.org/10.2310/7060.2004.17067

ACI (2020, May 5). "Economic Impact Assessment of COVID-19," Airports International Bulletin, May 5, 2020. Airports Council International. Retrieved from https://aci.aero/wp-content/uploads/2020/05/200505Third-Economic-Impact-Bulletin-FINAL.pdf

Adams, D. (2020, May 12). What to Do If an Airline Won't Refund Your Cancelled Flight. Forbes. Retrieved from https://www.forbes.com/sites/advisor/2020/05/12/what-to-do-if-an-airline-wont-refund-your-cancelledflight/\#4417d249711e

Adriano, L. (2020, July 24). Emirates to provide free COVID-19 cover. Business Insurance Canada. Retrieved from https://www.insurancebusinessmag.com/ca/news/breaking-news/emirates-to-provide-free-covid19cover-228787.aspx

Basnayake, H., Mack, C. and Tong, I. (2020, March 18). Covid-19 business continuity plan: Five ways to reshape. EY. Retrieved from https://www.ey.com/en_ca/transactions/companies-can-reshape-results-andplan-for-Covid-19-recovery https://www.ey.com/en_ca/transactions/companies-can-reshape-results-and-planfor-Covid-19- ca/

Bates, J. (2020, April 27). Report outlines new reality for airport retail post COVID-19. Airport World, The magazine for Airports Council International. Retrieved from https://airport-world.com/report-outlines-newreality-for-airport-retail-post-Covid-19/

Beard, J. (2020, July 3). How to get travel insurance with full coronavirus cover. The Telegraph. Retrieved from https://www.telegraph.co.uk/money/consumer-affairs/get-travel-insurance-full-coronavirus-cover/

Bellaiche, J. (2020, April 15). Impact of the Coronavirus on e-commerce: Update 7. ContentSquare. Retrieved from https://contentsquare.com/blog/impact-of-coronavirus-on-ecommerce-a-week-of-consolidation-andstabilization-update-7/

Bellaiche, J. (2020, April 15). Impact of the Coronavirus on e-commerce: Update 7. ContentSquare. Retrieved from https://contentsquare.com/blog/impact-of-coronavirus-on-ecommerce-a-week-of-consolidation-andstabilization-update-7/

Bi, Q., Wu, Y., Mei, S., Ye, C., Zou, X., Zhang, Z., Liu, X., Wei, L., Truelove, S. A., Zhang, T., Gao, W., Cheng, C., Tang, X., Wu, X., Wu, Y., Sun, B., Huang, S., Sun, Y., Zhang, J., Ma, T., ... Feng, T. (2020). Epidemiology and transmission of COVID-19 in 391 cases and 1286 of their close contacts in Shenzhen, China: a retrospective cohort study. The Lancet. Infectious diseases, 20(8), 911-919. Advance online publication. https://doi.org/10.1016/S1473-3099(20)30287-5

Bloom, L. B. (2020, April 26). Flight Attendants Warn: Leisure Travel Needs to Stop Now. Forbes. Retrieved from https://www.forbes.com/sites/laurabegleybloom/2020/04/26/flight-attendants-warning-airlines-stopflying/\#429967a445a0

Bostock, B. (2020, June 23). Saudi Arabia banned Hajj for international visitors this year due to the coronavirus, forfeiting as much as $\$ 4$ billion in revenue. Business Insider. Retrieved from https://www.businessinsider.com/saudi-arabia-coronavirus-ban-hajj-international-visitors-billions-lost-2020-6 
Burke, (2020, May 2). Battered Canadian airline industry pushing for government bailout. CBC. Retrieved from https://www.cbc.ca/news/politics/airlines-travel-covid-coronavirus-pandemic-1.5552511

Chitwood, K. (2020, June 25). Saudi Arabia has effectively canceled the hajj for most of the world's Muslims, saying the obligatory pilgrimage to Mecca will be "very limited" this year due to the coronavirus. Quartz Africa. Retrieved from https://qz.com/africa/1873433/saudi-hajj-Covid-19-cancellation-not-first-for-muslimpilgrims/

Chokshi, N. (2020, March 12). Airlines Cancel Flights and Lay Off Workers as Stocks Plummet. The New York Times. Retrieved from https:/www.nytimes.com/2020/03/12/business/economy/coronavirus-airlinestrump-europe.html

Clarke, T. (2020, April 10). SARS lessons can help P/ G. tourism rebound. Prince George Citizen. Retrieved from https://www.princegeorgecitizen.com/news/sars-lessons-can-help-p-g-tourism-industry-rebound1.24116417

Cochcran J. (2020, June 30). Your Guide to the Airlines' In-Flight Covid Safety Policies. Frommer's. Retrieved from https://www.frommers.com/tips/airfare/your-guide-to-the-airlines-in-flight-covid-safety-policies

Coronavirus disease named Covid-19 (2020, February 11). BBC News. Retrieved from https://www.bbc.com/news/world-asia-china-51466362

Coronavirus Travel Restrictions, Across the Globe (2020, March 26). The New York Times. Retrieved from https://www.nytimes.com/article/coronavirus-travel-restrictions.html

Cripps, K. (2020, April 16). Airline passengers undergo Covid-19 blood tests before boarding. Retrieved June 01, 2020, from https://edition.cnn.com/travel/article/emirates-passengers-blood-test-Covid-19/index.html

Drescher, C. (2020, May 13). How expensive will air travel be after the Covid-19 crisis? CNN Travel. Retrieved from https://www.cnn.com/travel/article/air-travel-expensive-coronavirus/index.html

Economist and YouGov (2020, March 18). How are US adults changing travel plans in response to Coronovirus? e-marketer. Retrieved from https:/www.emarketer.com/chart/235184/how-us-adultschanging-travel-plans-next-few-months-response-coronavirus-of-respondents-march-2020

Ellis, D, et al. (2020, May 9). Do airlines have a post-pandemic future. Asia Times. Retrieved from: https://asiatimes.com/2020/05/do-airlines-have-a-post-pandemic-future/

Evan, A. (2019, August 21). The 10 Airlines Officially Serve Up The Best Food. The Travel. Retrieved from: https://www.thetravel.com/best-airline-food/

Fauvelle, L. (2020, April 13). COVID-19: 7 specific impacts on the future of the aviation sector. Retrieved From: https://www.intotheminds.com/blog/en/Covid-19-impacts-aviation-sector/

Feldman, K. (2020, April 20). 15 deaths in the airline industry in 9 days linked to coronavirus. Why are planes still flying? Los Angeles Times. Retrieved from https://www.latimes.com/california/story/2020-0420/coronavirus-deaths-airline-industry-airplanes-flying

Fox, A. (2020, June 29). Hong Kong Airport Is Testing Full-body Disinfectant Machines That Clean Passengers' Clothing and Bodies. Travel \& Leisure. Retrieved from https://www.travelandleisure.com/airlinesairports/hong-kong-airport-full-body-machines-coronavirus-disinfecting

Fox, A. (2020, June 4). These new curved airline seat dividers could be the future of socially distanced plane travel. INSIDER Retrieved from https://www.insider.com/curved-airline-seat-dividers-future-plane-travelpost-coronavirus-2020-6

Fu, E. (2020, April 1). Timeline of Chinese Regime's Cover-up of COVID-19 Outbreak. The Epoch Times. Retrieved from https://www.theepochtimes.com/timeline-of-chinese-regimes-coverup-of-Covid-19outbreak_3291677.html

Gilbertson. D. (2020, July 2). Freaked out about full flights during a pandemic? These airlines are still blocking seats - for now. USA Today. Retrieved from https://www.usatoday.com/story/travel/airlinenews/2020/07/02/social-distancing-planes-which-airlines-still-blocking-seats/3281471001/

Givas, N. (2020, March 20). WHO haunted by old tweet saying China found no human transmission of coronavirus? New York Post. Retrieved from https://nypost.com/2020/03/20/who-haunted-by-old-tweetsaying-china-found-no-human-transmission-of-coronavirus/

Givas, N. (2020, March 20). WHO haunted by old tweet saying China found no human transmission of coronavirus. New York Post. Retrieved from https://nypost.com/2020/03/20/who-haunted-by-old-tweetsaying-china-found-no-human-transmission-of-coronavirus/

Global Web Index (2020, March). Coronavirus Research Series 2: Travel \& Commuting. Retrieved from https://www.globalwebindex.com/hubfs/2019_theme/GWI\%20Coronavirus\%20findings\%20\%20Travel\%20and\%20Comuting.pdf?_hsmi=84987042\&_hsenc=p2ANqtz-8SafN19Fi_ffrG0hEinYNY2f2rdXNmnnQAMixxdexmfAFWIVEAzAh5ZclObe7bfJYKxO

Goodway Group. (2020, April 15). How the Travel and Tourism Industry Has Had to Change Course. Goodway Group. Retrieved from https://goodwaygroup.com/blog/how-Covid-19-is-affecting-travel-and-tourism 
Guo, Y. R., Cao, Q. D., Hong, Z. S., Tan, Y. Y., Chen, S. D., Jin, H. J., Tan, K. S., Wang, D. Y., \& Yan, Y. (2020). The origin, transmission and clinical therapies on coronavirus disease 2019 (COVID-19) outbreak an update on the status. Military Medical Research, 7(1), 11. https://doi.org/10.1186/s40779-020-00240-0

Harry. S and Bloomberg. (2020, March 3). With 'Cabbage Prices' on Offer Amid Coronavirus Outbreak, Flights Across China Currently Cost as Little as \$13. Retrieved From: https://time.com/5794372/china-coronaviruscheap-flights/

Hoang, A., Chorath, K., Moreira, A., Evans, M., Burmeister-Morton, F., Burmeister, F., Naqvi, R., Petershack, M., \& Moreira, A. (2020). COVID-19 in 7780 pediatric patients: A systematic review. EClinical Medicine, Volume 24 July 2020, 100433. https://doi.org/10.1016/j.eclinm.2020.100433

Hong Kong International Airport. (2020, April 26). HKIA Applies Advanced Technology to Step Up Disinfection Against COVID-19. Retrieved 2 June 2020, from https://www.hongkongairport.com/en/mediacentre/press-release/2020/pr_1446

Horton, W. (2020, April 15). How the U.S. Is Distributing Airline Bailout Funds in COVID-19 Relief Deal. Forbes. Retrieved from https://www.forbes.com/sites/willhorton1/2020/04/15/how-the-us-is-distributingairline-bailout-funds-in-Covid-19-relief-deal/\#5c0161163a1d

Horton2, W/ (2020, June 4). Airlines Will Be Punished If Passengers Have COVID-19 Under China's New System for Flight and Travel Restrictions. Forbes. Retrieved from https://www.forbes.com/sites/willhorton1/2020/06/04/airlines-will-be-punished-if-passengers-have-Covid19-under-chinas-new-system-for-flight-and-travel-restrictions/\#44e0f6395e20

Hosseiny, M., Kooraki, S., Gholamrezanezhad, A., Reddy, S., \& Myers, L. (2020). Radiology Perspective of Coronavirus Disease 2019 (COVID-19): Lessons from Severe Acute Respiratory Syndrome and Middle East Respiratory Syndrome. AJR. American journal of Roentgenology, 214(5), 1078-1082. https://doi.org/10.2214/AJR.20.22969

Howland, D. (2020, April 8). Away sales plummet 90\% as COVID-19 curtails travel. Retail Dive. Retrieved from: https://www.retaildive.com/news/away-sales-plummet-90-as-Covid-19-curtails-travel/575708/

Hutton, M. (2020, May 8). 'Coronavirus crisis tourists': fleeing the pandemic is not only selfish, it's a privilege only the rich can afford. South China Morning Post. Retrieved from ht-tps://www.scmp.com/magazines/postmagazine/travel/article/3078814/coronavirus-crisis-tourists-fleeing-pandemic-not

IATA (2020, April 24). COVID-19 Impact on Asia-Pacific Aviation Worsens. International Air Transport Association. Retrieved from https://www.iata.org/en/pressroom/pr/2020-04-24-01/

IATA (2020, April 7). 25 Million Jobs at Risk with Airline Shutdown. International Air Transport Association. Retrieved from https://www.iata.org/en/pressroom/pr/2020-04-07-02/

IATA (2020, June). Airline Industry Economic Performance. Industry Fact Sheet, June 2020. International Air Transport Association. Retrieved from https://www.iata.org/en/iata-repository/publications/economicreports/airline-industry-economic-performance-june-2020-data-tables/

IATA (2020, March 24). Remarks of Alexandre de Junaid at the IATA Media Briefing on COVID-19, 24 March 2020. International Air Transport Association. Retrieved from https://www.iata.org/en/pressroom/speeches/2020-03-24-01/

IATA. (2020, April 24). COVID-19 Impact on Asia-Pacific Aviation Worsens. Retrieved 2 June 2020, from https://www.iata.org/en/pressroom/pr/2020-04-24-01/

ICAO (2020, June 22). Effects of Novel Coronavirus (COVID-19) on Civil Aviation: Economic Impact Analysis. Air Transport Bureau, International Civil Aviation Organization. Retrieved from https://www.icao.int/sustainability/Documents/COVID-19/ICAO_Coronavirus_Econ_Impact.pdf

IMF (2020, June). “A Crisis Like No Other, An Uncertain Recovery,” World Economic Outlook Update. International Monetary Fund. Retrieved from file://C:/Users/peakm/Downloads/WEOENG202006.pdf

Janssen, P. (2020, May 19). Thai Airways crash lands into bankruptcy court. Asia Times. Retrieved from https://asiatimes.com/2020/05/thai-airways-crash-lands-into-bankruptcy-court/

Jeremy Dexter (2019, February 7). Three ways airlines can automate passenger communications to manage disruption. Retrieved from: https://imimobile.com/blog/3-ways-airlines-can-automate-passengercommunications-to-prevent-and-manage-disruption

Johanis, D. (2007). How Toronto Pearson International Airport applied lessons from SARS to develop a pandemic response plan. Journal of Business Continuity \& Emergency Planning, 1 (4), 356-368 (2007)

Johnson Tew, P., Lu, Z., Tolomiczenko, G. and Gellatly, J. (2008), "SARS: lessons in strategic planning for hoteliers and destination marketers", International Journal of Contemporary Hospitality Management, Vol. 20 No. 3, pp. 332-346. https://doi.org/10.1108/09596110810866145

Jones, K. (2020, April 8). The Pandemic Economy: What are Shoppers Buying Online During COVID-19? Retrieved from: https://www.visualcapitalist.com/shoppers-buying-online-ecommerce-Covid-19/

Kemp, S. (2020, April 23). Digital 2020: April Global Stat shot — Data Reportal - Global Digital Insights. Retrieved 1 June 2020, from https://datareportal.com/reports/digital-2020-april-global-statshot 
Koenig, D. (2020, June 27). American Airlines, United Airlines end social distancing, will book flights to full capacity. Chicago Sun Times. Retrieved from https://chicago.suntimes.com/2020/6/26/21305022/americanunited-airlines-end-social-distancing

Koenig, D. (2020, May 08). Can you properly socially distance on an airplane? Retrieved from: https://www.afar.com/magazine/can-you-properly-socially-distance-on-an-airplane

Kong, X. (2020, March 16). Covid-19: What the MCO means. Focus Malaysia. Retrieved from https://focusmalaysia.my/mainstream/Covid-19-what-the-mco-means/

Kong, X. (2020, March 16). Covid-19: What the MCO means. Focus Malaysia. Retrieved from https://focusmalaysia.my/mainstream/Covid-19-what-the-mco-means/

LeDuc, J. W., \& Barry, M. A. (2004). SARS, the First Pandemic of the 21st Century. Emerging Infectious Diseases, 10(11), e26. https://doi.org/10.3201/eid1011.040797_02

Lloyd-Jones, A. R. (2020, February 2). Pandemics and the Lodging Industry, HVS. Retrieved from https://www.hvs.com/article/8688-Pandemics-and-the-Lodging-Industry

Mariano, K. (2020, May 15). Airline ticket prices will dip after coronavirus - study. Travel Daily. Retrieved from: https://www.traveldailymedia.com/airline-ticket-prices-will-dip-after-coronavirus-study/

Mason, F. (2020, February 26). Trump says may need to restrict travel from Italy, South Korea. Reuters. Retrieved from https://www.reuters.com/article/us-china-health-usa-travel/trump-says-may-need-to-restricttravel-from-italy-south-korea-idUSKCN20L01B

McDonald, M. D. (2020, March 11). It's Coronavirus-Free, But El Salvador Is Banning All Foreign Travelers. Bloomberg. Retrieved from https://www.bloomberg.com/news/articles/2020-03-11/nation-with-nocoronavirus-bans-visitors-and-quarantines-locals

McKeever, A. (2010, March 6). Here's how coronavirus spreads on a plane - and the safest place to sit. National Geographic. Retrieved from https://www.nationalgeographic.com/science/2020/01/howcoronavirus-spreads-on-a-plane/

Moon, L. (2020, May 15). Luggage giant Samsonite suffers first-quarter loss of US\$787 million as Covid-19 brings global travel to a standstill. Retrieved from: https://www.scmp.com/business/companies/article/3084507/luggage-giant-samsonites-suffers-first-quarterloss-us 787

Mzezewa, T. (2020, May 27). Thinking About Flying? Here's What You Need to Know Now. Retrieved 3 June 2020, from https://www.nytimes.com/2020/05/27/travel/is-flying-safe-coronavirus.html

O' Connell, L. (2020, May 28). Total revenue of Samsonite worldwide from 2007 to 2019. Retrieved from: https://www.statista.com/statistics/252796/total-revenue-of-samsonite-worldwide/

Oxford Economics (2020, March 16). The Economic Impact of the Coronavirus Due to Travel Losses. Retrieved from

https://www.ustravel.org/sites/default/files/media_root/document/Coronavirus_2020_Impacts_WEB.pdf?utm _source=MagnetMail\&utm_medium=email\&utm_content=3.17.20-Press-

RogerWHMeeting\&utm_campaign=pr

Pentol, A. (2020, April 23). Covid-19: Dufry declares 70\% revenue drop in 2020 as 'worst case scenario.' TR Business. Retrieved from https://www.trbusiness.com/regional-news/international/Covid-19-dufry-declares70-revenue-decrease-in-2020-as-worst-case-scenario/187041.

Petchenik, I. (2020, April 02). Tracking March's historic drop in air traffic | Flightradar24 Blog. Retrieved 2 June 2020, from https://www.flightradar24.com/blog/tracking-marchs-historic-drop-in-air-traffic/

Peter. J. (2020, May 19). Thai Airways crash lands into bankruptcy court. Retrieved from: https://asiatimes.com/2020/05/thai-airways-crash-lands-into-bankruptcy-court/

Proteau, M. (2020, March 30). Government announces support for air transportation sector during COVID-19 pandemic. Department of Finance, Government of Canada. Retrieved from https://www.canada.ca/en/department-finance/news/2020/03/government-announces-support-for-airtransportation-sector-during-Covid-19-pandemic.html

Rizzo, C. (2020, April 24). Airplane Cabin Designers Unveil Potential Plane Seat Ideas for When We Can Travel Again. INSIDER Retrieved from https://www.travelandleisure.com/culture-design/aviointeriors-janusbubble-airplane-seat-design

Rosen, E. (2019, November 27). The 2020 List of The World's Best Airlines Is Out Now. Forbes. Retrieved from https://www.forbes.com/sites/ericrosen/2019/11/27/the-2020-list-of-the-worlds-best-airlines-is-outnow/\#78dd5e0116e3

Russell, A. (20, March 26). Coronavirus: How is Canada planning to enforce mandatory self-isolation? Global News. Retrieved from https://globalnews.ca/news/6736381/coronavirus-canada-quarantine-act-mandatoryself-isolation/

Salcedo, A., Yar, S. \& Cherelus. G. (2020, May 8). Corona Travel Restrictions, All Over the Globe. Retrieved from https://www.nytimes.com/article/coronavirus-travel-restrictions.html 
Saudi Arabia (2020, July 30). Worldometer. $\quad$ Retrieved from https://www.worldometers.info/coronavirus/country/saudi-arabia/

Sehl, K., (2020), How the Airline Industry Survived SARS, 9/11, the Global Recession and More, https://apex.aero/articles/aftershocks-coronavirus-impact/

Shafiee, M.M., Sanayei, A., Shahin, A. and Dolatabadi, H.R. (2014) 'The role of brand image informing airlines passengers' purchase intention: a study of Iran aviation industry', Int. J. Services and Operations Management, Vol. 19, No. 3, pp.360-376. Retrieved from: https://www.researchgate.net/publication/280769485_The_role_of_brand_image_in_forming_airlines_passen gers'_purchase_intention_Study_of_Iran_aviation_industry/link/57a20d9008aeef8f311e0c83/download

Sheth, K. (2019, March 15). Countries That Travel the Most. World Atlas. Retrieved from https://www.worldatlas.com/articles/countries-whose-citizens-travel-the-most.html

Sheth, K. (2019, March 15). Countries That Travel the Most. World Atlas. Retrieved from https://www.worldatlas.com/articles/countries-whose-citizens-travel-the-most.html

Slotnick, D. (2020, May 12). Some of the world's airlines could go bankrupt because of the COVID-19 crisis, according to an aviation consultancy. See the carriers that have already collapsed because of the pandemic. Retrieved from: https://www.businessinsider.com/coronavirus-airlines-that-failed-bankrupt-covid19pandemic-2020-3\#flybe-uk-march-2020-1

Slotnick, D. (2020, May 12). Some of the world's airlines could go bankrupt because of the COVID-19 crisis, according to an aviation consultancy. See the carriers that have already collapsed because of the pandemic. Retrieved from: https://www.businessinsider.com/coronavirus-airlines-that-failed-bankrupt-covid19pandemic-2020-3\#flybe-uk-march-2020-1

Slotnick2, D. (2020, March 27). Airlines will get the $\$ 60$ billion bailout they asked for in the $\$ 2$ trillion coronavirus stimulus bill that Trump signed into law. It also prohibits layoffs, stock buybacks, and dividends. Business Insider. Retrieved from https://www.businessinsider.com/airlines-coronavirus-bailout-senate-stockbuybacks-2020-3

Statista (May 11, 2020). Estimated impact of coronavirus on revenues of air transport industry in Italy 2020. Retrieved from: https://www.statista.com/statistics/1105045/estimated-impact-of-coronavirus-on-revenuesof-air-transport-industry-in-italy/

Statista. (2020, April 30). Passenger load factor (PLF) of international flights in 2020. Retrieved 2 June 2020, from https://www.statista.com/statistics/234955/passenger-load-factor-plf-on-international-flights/

Stockdill, R. (2020, May 15). Samsonite sales plunge 80 per cent as travel all but halts. Retrieved from: https://insideretail.asia/2020/05/15/samsonite-sales-plunge-80-per-cent-as-travel-all-but-halts/

Street, F. (2020, June 17). Is this double-decker seat the future of airplane travel? CNN Travel. Retrieved from https://www.cnn.com/travel/article/zephyr-seat-double-decker-airplane/index.html

Suhartono, H. (2020, March 3). Just \$13 to fly across China as airlines struggle to fill seats. Bloomberg. Retrieved from https://www.msn.com/en-us/money/companies/just-13-to-fly-across-china-as-airlinesstruggle-to-fill-seats/ar-BB10F2Nz

Tay, M. Z., Poh, C. M., Rénia, L., MacAry, P. A., \& Ng, L. (2020). The trinity of COVID-19: immunity, inflammation and intervention. Nature reviews. Immunology, 20(6), 363-374. https://doi.org/10.1038/s41577-020-0311-8

The Economist. (2020, March 15). Coronavirus is grounding the world's airlines. Retrieved from https://www.economist.com/business/2020/03/15/coronavirus-is-grounding-the-worlds-airlines

The Novel Coronavirus. (n.d.). State of Israel Ministry of Health. Retrieved from https://govextra.gov.il/ministry-of-health/corona/corona-virus-en/

TOI Staff. (2020 March 6). Israel begins restrictions on visitors from 5 European nations over virus fears. Times of Israel. Retrieved from https://www.timesofisrael.com/israel-begins-restrictions-on-visitors-from-5european-nations-over-virus-fears/

TSA (2020, June 29). Coronavirus (COVID-19) information. Transportation Security Administration. Retrieved from https://www.tsa.gov/coronavirus

Tyler, T. (2015, June 18). Enhancing the government relationship. IATA. Retrieved from: https://airlines.iata.org/news/enhancing-the-government-relationship

UNWTO (2020, May). UNWTO World Tourism Barometer - Special Focus on the Impact of COVID-19. United Nations World Tourism Organization. Retrieved from https://www.eunwto.org/doi/pdf/10.18111/9789284421817

Updated WHO recommendations for international traffic in relation to COVID-19 outbreak (2020, February 29). World Health Organization. Retrieved from https://www.who.int/news-room/articles-detail/updated-whorecommendations-for-international-traffic-in-relation-to-Covid-19-outbreak

Wallace, G., \& Rokus, B. (2020, April 28). JetBlue to become first major US airline to require passengers to wear face coverings. Retrieved June 01, 2020, from https://edition.cnn.com/2020/04/28/business/jetblue-facemasks/index.html 
Whitmore, G. (2020, March 10). How Airlines Are Fighting Coronavirus \& Their Update Pages. Forbes. Retrieved from https://www.forbes.com/sites/geoffwhitmore/2020/03/10/how-airlines-are-fightingcoronavirus--their-update-pages/\#22fbf4d24230

WHO (2010). International Travel and Health (p. 22). International Health Regulations Secretariat, Communicable Diseases, World Health Organization, Geneva.

WHO announces COVID-19 outbreak a pandemic. (2020, March 12). World Health Organization. Retrieved from https://www.euro.who.int/en/health-topics/health-emergencies/coronavirus-Covid19/news/news/2020/3/who-announces-Covid-19-outbreak-a-pandemic

WHO Timeline - Covid-19, 2020 (2020. April 27). World Health Organization. Retrieved from https://www.who.int/news-room/detail/27-04-2020-who-timeline---Covid-19

Wilder-Smith A. (2006). The severe acute respiratory syndrome: impact on travel and tourism. Travel medicine and infectious disease, 4(2), 53-60. https://doi.org/10.1016/j.tmaid.2005.04.004

Wilson, B. (2020, March 16). Mongolia Announces 3 New COVID-19 Cases, totaling 4: How They Got $\begin{array}{lllll}\text { Coronavirus } & \text { Precautions } & \text { Right. } & \text { Forbes. } & \text { Retrieved }\end{array}$ https://www.forbes.com/sites/breannawilson/2020/03/16/mongolia-announces-3-new-Covid-19-casestotaling-4-how-they-got-coronavirus-precautions-right/\#4318fd24fc9e

WONG, L. (2020, March 17). Coronavirus: Singaporean students studying overseas encouraged to return home soon, says MFA. Retrieved 3 June 2020, from https://www.straitstimes.com/singapore/coronavirussingaporean-students-studying-overseas-encouraged-to-return-home-soon-mfa

World Bank (2020, June 8). The Global Economic Outlook during the Covid-19 Pandemic: A Changed World. The World Bank. Retrieved from https://www.worldbank.org/en/news/feature/2020/06/08/the-globaleconomic-outlook-during-the-Covid-19-pandemic-a-changed-world

Worldometer (2020, July 11). Coronavirus/Countries. $\quad$ Retrieved from https://www.worldometers.info/coronavirus/countries-where-coronavirus-has-spread/

WTO (2020, April 8). Trade set to plunge as COVID-19 pandemic upends global economy. World Trade Organization. Retrieved from https://www.wto.org/english/news_e/pres20_e/pr855_e.htm

Ye, Z., Wang, Y., Colunga-Lozano, L. E., Prasad, M., Tangamornsuksan, W., Rochwerg, B., Yao, L., Motaghi, S., Couban, R. J., Ghadimi, M., Bala, M. M., Gomaa, H., Fang, F., Xiao, Y., \& Guyatt, G. H. (2020). Efficacy and safety of corticosteroids in COVID-19 based on evidence for COVID-19, other coronavirus infections, influenza, community-acquired pneumonia and acute respiratory distress syndrome: a systematic review and meta-analysis. CMAJ : Canadian Medical Association journal = journal de l'Association médicale canadienne, 192(27), E756-E767. https://doi.org/10.1503/cmaj.200645

Yeung, J. (2020, February 27). A global coronavirus: travel bans, face masks and fear. CNN. Retrieved from https://www.cnn.com/2020/02/27/world/gallery/coronavirus-prevention/index.html

Yi, T. X. (2020, May 10). Malaysia's movement control order to be extended further until Jun 9, says PM Muhyiddin. Channel News Asia. Retrieved from https:/www.channelnewsasia.com/news/asia/malaysiaCovid-19-muhyiddin-movement-control-order-jun-9-extend-12718738

Yuki, K., Fujiogi, M., \& Koutsogiannaki, S. (2020). COVID-19 pathophysiology: A review. Clinical immunology (Orlando, Fla.), 215, 108427. https://doi.org/10.1016/j.clim.2020.108427

Zeng, B., Carter, R. W. \& Lacy, T. D. (2005). Short-term Perturbations and Tourism Effects: The Case of SARS in China, Current Issues in Tourism, 8:4, 306-322, DOI: 10.1080/13683500508668220

Zhang, R., Li, Y., Zhang, A. L., Wang, Y., \& Molina, M. J. (2020). Identifying airborne transmission as the dominant route for the spread of COVID-19. Proceedings of the National Academy of Sciences of the United States of America, 117(26), 14857-14863. https://doi.org/10.1073/pnas.2009637117.

Appendix 1: Identification of Challenges from Literature Review

\begin{tabular}{|c|c|c|c|c|}
\hline \multirow{2}{*}{ Author } & \multicolumn{4}{|c|}{ Challenges } \\
\cline { 2 - 5 } & $\begin{array}{c}\text { Financial } \\
\text { Crisis }\end{array}$ & $\begin{array}{c}\text { Government } \\
\text { policies }\end{array}$ & $\begin{array}{c}\text { Consumer } \\
\text { mistrust }\end{array}$ & Travel retail \\
\hline Daphne. H. & & & Yes & Yes \\
\hline Fauvelle, L. & Yes & & & \\
\hline $\begin{array}{c}\text { Harry. S and } \\
\text { Bloomberg. }\end{array}$ & Yes & & & Yes \\
\hline IATA & Yes & & & Yes \\
\hline Katie. J & & & & Yes \\
\hline Liam. O. & & & & Yes \\
\hline Louise. M. & & & & \multicolumn{2}{c}{} \\
\hline Peter. J. & Yes & & & \\
\hline Robert. S. & & & & \\
\hline
\end{tabular}




\begin{tabular}{|c|c|c|c|c|}
\hline Slotnick, D. & Yes & Yes & & \\
\hline Statista & Yes & Yes & & \\
\hline The Economist & & & Yes & \\
\hline
\end{tabular}

